\title{
NON-NEOPLASTIC LESIONS INCLUDING CANCER MIMICS IN BENIGN PROSTATIC HYPERPLASIA
}

\author{
Surinder Kumar Atri1, Virender Mohan Rana², Monica Pangotra³, Rahul Gupta ${ }^{4}$
}

${ }_{1}^{1}$ Associate Professor, Department of Pathology, Government Medical College, Jammu, Jammu and Kashmir. 2 Demonstrator, Department of Pathology, Government Medical College, Jammu, Jammu and Kashmir.

${ }_{3}^{3}$ Postgraduate Student, Department of Pathology, Government Medical College, Jammu, Jammu and Kashmir. ${ }^{4}$ Associate Professor, Department of Urology, Government Medical College, Jammu, Jammu and Kashmir.

ABSTRACT
BACKGROUND
Transurethral resection of prostate and prostatic biopsies are very common specimens in surgical pathology. Prostatic biopsies are
done in cases where there is clinical suspicion of malignancy. These specimens have to be thoroughly examined to avoid false
negative diagnosis of adenocarcinoma prostate. Morphological lesions in benign nodular hyperplasia that mimic adenocarcinoma
can be broadly divided into those that mimic low-grade adenocarcinoma (Gleason grade $\leq 3$ ) and those that mimic high-grade
tumours. Non-neoplastic lesions which are to be distinguished from adenocarcinoma prostate are atrophy including partial
atrophy, atypical adenomatous hyperplasia (adenosis), crowded benign glands, sclerosing adenosis, radiation atypia in benign
glands, basal cell hyperplasia, clear cell hyperplasia, cribriform hyperplasia, non-specific granulomatous prostatitis, dense
inflammation and malakoplakia, Signet ring-like change in non-epithelial cells, prostatic xanthoma and paraganglia.
The aims of this study is to evaluate the spectrum of histomorphological lesions in benign nodular hyperplasia and to review
the histomorphological features in cancer mimickers and how to distinguish them from adenocarcinoma prostate.
The objective of this study is to evaluate and review the different cancer mimickers in benign nodular hyperplasia.

\section{MATERIALS AND METHODS}

It is a descriptive study from Jan. 2012 to Dec. 2014; 221 cases were identified in this period. All these cases were reviewed and incidence of various non-neoplastic lesions was evaluated. Statistical analysis was performed using SPSS 10.0 for Windows student version (SPSS Inc., 233 South Wacker Drive, 11 th Floor, Chicago, IL 60606-6412).

\section{RESULTS}

Age of the patients ranged from 38 to 103 years. Common clinical presentation was obstructive symptoms (71.1\%) and irritative symptoms (28.9\%). Of the total 221 specimens, 203 were TURP specimens and 18 were open prostatectomy specimens. Incidence of various lesions was glandulostromal hyperplasia: $97.3 \%$, stromal hyperplasia: $2.71 \%$, corpora amylacea: $68 \%$, cystically dilated glands: $92 \%$, acute prostatitis: $1.2 \%$, chronic prostatitis: $18.6 \%$, papillary infoldings: $53.2 \%$, proteinaceous material: $13.54 \%$, infarct: $22 \%$, gland necrosis: $4.22 \%$, calcification: $0.82 \%$, squamous metaplasia: $6 \%$, transitional metaplasia: $2.5 \%$, basal cell hyperplasia: $4.5 \%$, cribriform hyperplasia: $0.45 \%$, atrophy: $6 \%$, post-atrophic hyperplasia: $25 \%$, partial atrophy: $0.5 \%$, atypical adenomatous hyperplasia: $8 \%$ of cases, crowded benign glands: $96 \%$, sclerosing adenosis: $1.5 \%$ and reactive epithelial atypia: $22 \%$.

\section{CONCLUSION}

Histomorphological lesions in the differential diagnosis of adenocarcinoma prostate are atrophy including partial atrophy, atypical adenomatous hyperplasia, basal cell hyperplasia, cribriform hyperplasia and crowded benign glands. These lesions mimic adenocarcinoma prostate (Gleason grade $<3$ ).

\section{KEYWORDS}

Benign Prostatic Hyperplasia, Cancer Mimickers, Adenocarcinoma and Histomorphological.

HOW TO CITE THIS ARTICLE: Atri SK, Rana VM, Pangotra M, et al. Non-neoplastic lesions including cancer mimics in benign prostatic hyperplasia. J. Evolution Med. Dent. Sci. 2017;6(89):6208-6213, DOI: 10.14260/jemds/2017/1350

'Financial or Other Competing Interest': None.

Submission 03-10-2017, Peer Review 27-10-2017,

Acceptance 02-11-2017, Published 13-11-2017.

Corresponding Author:

Dr. Surinder Kumar Atri,

Associate Professor,

House No. 24, Lane 51,

Behind Sunny Farms,

Greater Kailash Post Office,

Gangyal, Jammu-180010,

Jammu and Kashmir.

E-mail: surinderkumaratri@gmail.com

DOI: $10.14260 /$ jemds $/ 2017 / 1350$

\section{(c) (i) $(5)$}

\section{BACKGROUND}

Benign prostatic hyperplasia is an extremely common disorder in elderly men that affects more than $70 \%$ of men by 60 years of age. It is characterised by proliferation of prostatic epithelial and stromal cells resulting in enlargement of prostate. ${ }^{1}$ The incidence of benign prostatic hyperplasia increases with age. It is seen in $20 \%$ of men by 40 years of age, $70 \%$ of men by age 60 years and $90 \%$ of men by age 80 years. ${ }^{2}$

There is no direct correlation between histologic changes and appearance of clinical symptoms. Benign prostatic hyperplasia usually affects periurethral region of prostate resulting in the formation of large, discrete nodules. These nodules compress the urethra and patient presents with 
lower urinary tract symptoms. Only $50 \%$ of those who have microscopic evidence of hyperplasia have clinically detectable enlargement of prostate and only $50 \%$ of those who have clinical evidence of prostate enlargement develop clinical symptoms (LUTS). 3 These patients present with symptoms of increased urinary frequency, nocturia, difficulty in starting and stopping the streams of urine, overflow dribbling, dysuria and acute urinary retention. ${ }^{4}$ Mild cases of benign prostatic hyperplasia are treated without medical or surgical therapy. Moderate to severe cases recalcitrant to medical therapy are treated with surgical therapy. ${ }^{4}$ Transurethral resection of prostate is gold standard for surgical therapy of benign prostatic hyperplasia. 5 Transurethral resection of prostate and prostatic biopsies are very common specimens in surgical pathology. Prostatic biopsies are done in cases where there is clinical suspicion of malignancy. ${ }^{6}$ There is huge burden of these patients on health care system and as a result hundreds of crores of money is used for the treatment of benign prostatic hyperplasia. This load is increasing in developing countries like India where life expectancy is increasing because of improving economic conditions and improving health care facilities, the number of people more than 60 years of age are increasing, thereby increasing the number of people with benign prostatic hyperplasia. Carcinoma prostate is the most common cancer in men and occurs in this age group only. ${ }^{7}$ Transurethral resection specimens have to be thoroughly examined to avoid false negative diagnosis of adenocarcinoma prostate. Morphological lesions in benign nodular hyperplasia that mimic adenocarcinoma can be broadly divided into those that mimic low-grade adenocarcinoma (Gleason grade $\leq 3$ ) and those that mimic high-grade tumours.8,9 Morphological classification of these lesions based on the architectural patterns seen in routine haematoxylin and eosin ( $\mathrm{H}$ and $\mathrm{E})$ stained sections is shown in table given below. ${ }^{10}$

\begin{tabular}{|c|c|c|}
\hline $\begin{array}{c}\text { Architectural } \\
\text { Pattern }\end{array}$ & $\begin{array}{l}\text { Non-Neoplastic } \\
\text { Prostate Lesions }\end{array}$ & \begin{tabular}{|c|} 
Types of Prostate \\
Carcinoma \\
Mimicked
\end{tabular} \\
\hline $\begin{array}{l}\text { Small gland } \\
\text { pattern }\end{array}$ & $\begin{array}{c}\text { Lesions of prostatic } \\
\text { epithelial origin } \\
\text { Atrophy including partial } \\
\text { atrophy } \\
\text { Atypical adenomatous } \\
\text { hyperplasia (adenosis) } \\
\text { Crowded, benign glands } \\
\text { Sclerosing adenosis } \\
\text { Radiation atypia in benign } \\
\text { glands } \\
\text { Basal cell hyperplasia }\end{array}$ & $\begin{array}{c}\text { Gleason pattern } \\
\quad \leq 3 \\
\text { Atrophic PCa }\end{array}$ \\
\hline $\begin{array}{l}\text { Large and } \\
\text { cribriform } \\
\text { gland patterns }\end{array}$ & \begin{tabular}{|} 
Basal cell hyperplasia \\
Clear cell cribriform \\
hyperplasia \\
Medium-to-large sized \\
hyperplastic glands \\
Reactive epithelial atypia
\end{tabular} & $\begin{array}{c}\text { Cribriform Gleason } \\
\text { patterns 3, } 4 \text { and } 5 \\
\text { Ductal } \\
\text { adenocarcinoma } \\
\text { Pseudo- } \\
\text { hyperplastic }\end{array}$ \\
\hline $\begin{array}{l}\text { Solid and non- } \\
\text { glandular } \\
\text { patterns }\end{array}$ & \begin{tabular}{|c|} 
Non-specific \\
granulomatous prostatitis, \\
dense inflammation and
\end{tabular} & $\begin{array}{l}\text { Gleason patterns } \\
4 \text { and } 5 \\
\text { Foamy gland }\end{array}$ \\
\hline
\end{tabular}

\begin{tabular}{|l|c|c|}
\hline & $\begin{array}{c}\text { malakoplakia } \\
\text { Signet ring-like change in } \\
\text { non-epithelial cells } \\
\text { Prostatic xanthoma } \\
\text { Paraganglia }\end{array}$ & $\begin{array}{c}\text { Post-treatment } \\
\text { carcinoma }\end{array}$ \\
\hline $\begin{array}{c}\text { Table 1. Morphological Lesions in the Differential Diagnosis } \\
\text { of Adenocarcinoma Prostate including Cancers Mimicked }\end{array}$ \\
\hline
\end{tabular}

PCa, Prostatic adenocarcinoma

Therefore, we planned this study to evaluate the spectrum of non-neoplastic lesions, especially cancer mimics in these specimens.

\section{MATERIALS AND METHODS}

It is a descriptive study. All cases of benign prostatic hyperplasia signed out in the Department of Pathology from January 2012 to Dec. 2014 were retrieved from surgical pathology files and consult files of Govt. Medical College, Jammu. In total, 221 cases were identified over a period of three years. Haematoxylin and eosin stained sections of $5 \mu \mathrm{m}$ thickness were re-examined in all cases to evaluate the following histologic features: Glandulostromal proliferationstromal or glandular predominance, corpora amylacea, cystically dilated glands, papillary infoldings, lymphocytic collections/ infiltration, homogenous eosinophilic material, gland necrosis, acute prostatitis, chronic prostatitis, nonspecific granulomatous prostatitis, malakoplakia, prostate xanthoma, atrophy, post-atrophic hyperplasia, partial atrophy, atypical adenomatous hyperplasia [AAH] (adenosis), Crowded benign glands, sclerosing adenosis and radiation atypia in benign glands. Hyperplastic glands, reactive epithelial atypia, squamous metaplasia, transitional metaplasia, basal cell hyperplasia and cribriform hyperplasia. Clinical features and follow-up data was obtained from consult files and referring surgeons. Statistical analysis was performed using SPSS 10.0 for Windows student version (SPSS Inc., 233 South Wacker Drive, 11 $1^{\text {th }}$ Floor, Chicago, IL 60606-6412).

\section{RESULTS}

Age of the patients ranged from 38 to 103 years and most patients were in $6^{\text {th }}$ and $7^{\text {th }}$ decade of life. The common clinical presentation was obstructive symptoms (71.1\%) and irritative symptoms (28.9\%). Common clinical symptoms were hesitancy followed by poor urine flow and increased frequency of urination. Of the total 221 specimens, 203 were TURP specimens and 18 were open prostatectomy specimens. All cases included in the study had glandulostromal hyperplasia and only 6 (2.71\%) cases showed predominantly stromal pattern. Corpora amylacea was present in $68 \%$ of cases. Cystically dilated glands were present in $92 \%$ of cases. Acute and chronic prostatitis was observed in $1.2 \%$ and $18.6 \%$ of cases respectively. Papillary infoldings was seen in $53.2 \%$ of cases and Proteinaceous material in $13.54 \%$ of cases. Infarct and gland necrosis was seen in $22 \%$ and $4.22 \%$ of cases respectively. Calcification in only $0.82 \%$ of cases. Among metaplasias squamous and transitional metaplasia was seen in $6 \%$ and $2.5 \%$ of cases. 
Basal cell hyperplasia was seen in $4.5 \%$ of cases and cribriform hyperplasia in $0.45 \%$ of cases. The incidence of atrophy was seen in $6 \%$, post-atrophic hyperplasia in $2 \%$ and that of partial atrophy was seen in $0.5 \%$. Atypical adenomatous hyperplasia was seen in $8 \%$ of cases. Crowded benign glands was very frequent finding (96\%). Sclerosing adenosis was identified in $1.5 \%$ of cases. Reactive epithelial atypia was seen in $22 \%$ of cases. Xanthoma prostate or granulomatous prostatitis was not identified in any case.

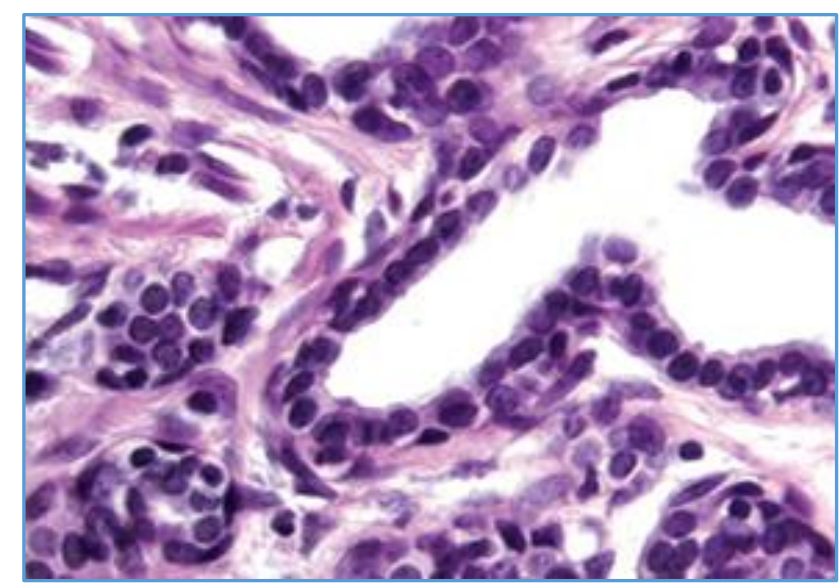

Figure 1. Microphotograph of a Case of Simple Atrophy (400X)

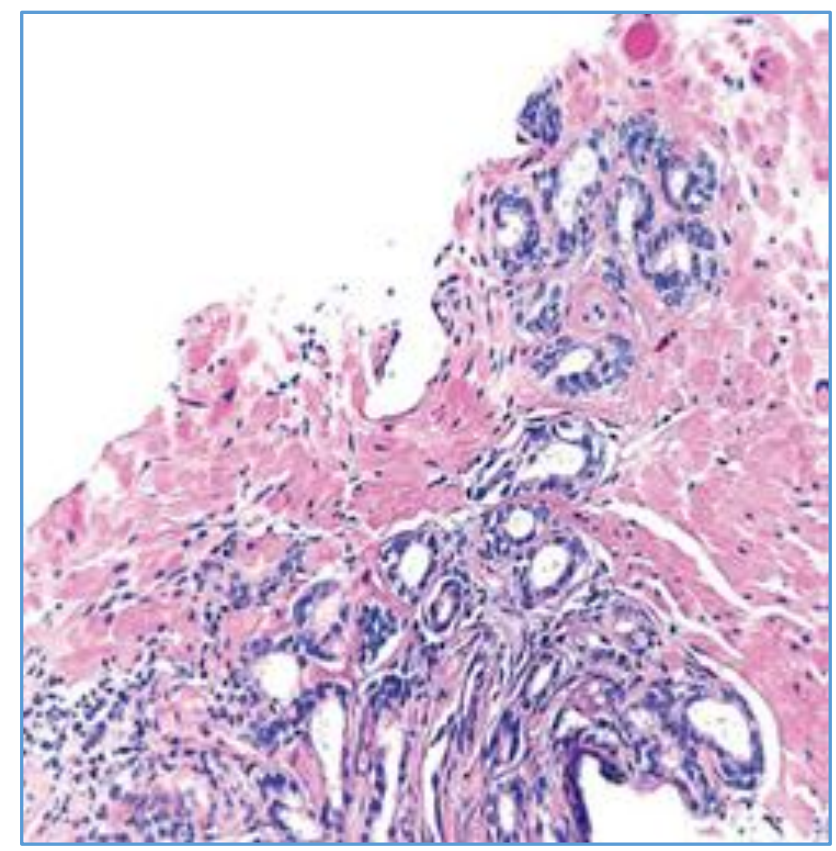

Figure 2. Microphotograph of a Case of Post-Atrophic Hyperplasia (100X)

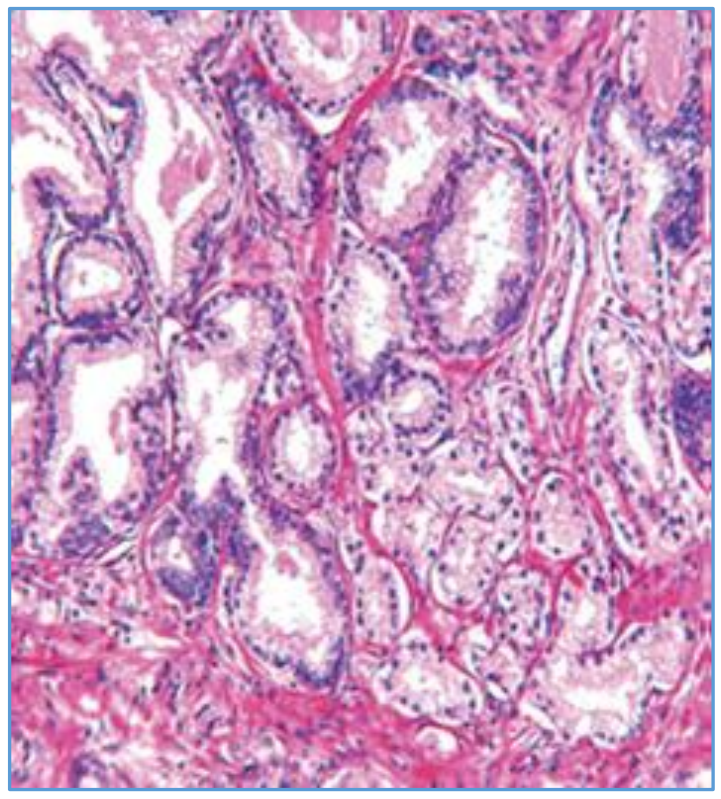

Figure 3. Microphotograph of a Case of Atypical Adenomatous Hyperplasia (100X)

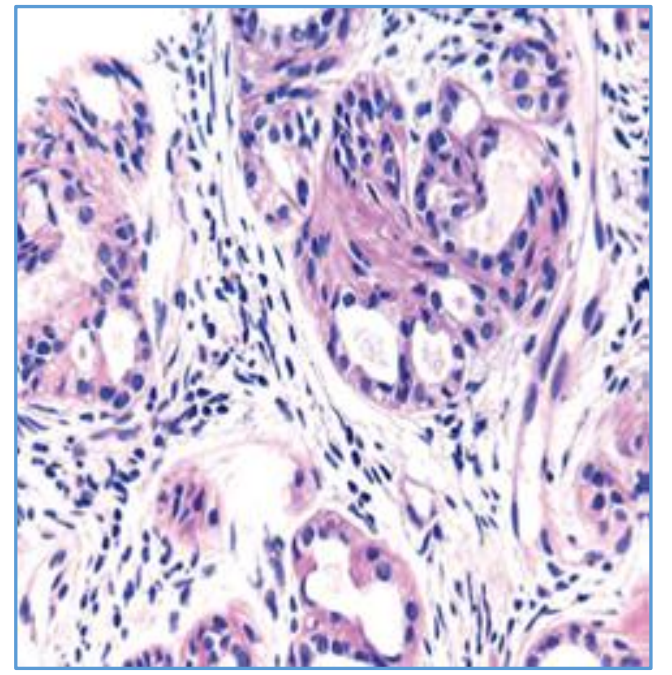

Figure 4. Microphotograph of a Case of Sclerosing Adenosis

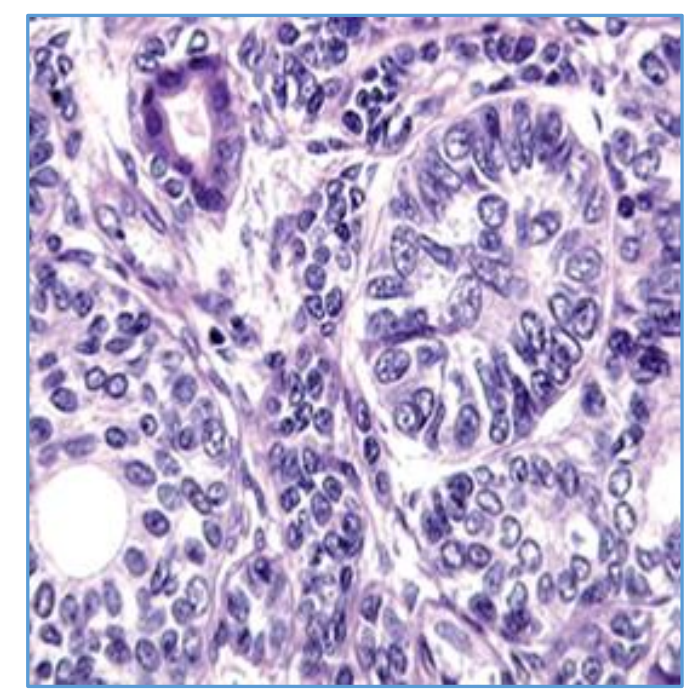

Figure 5. Microphotograph of a Case of Basal Cell Hyperplasia (400X) 


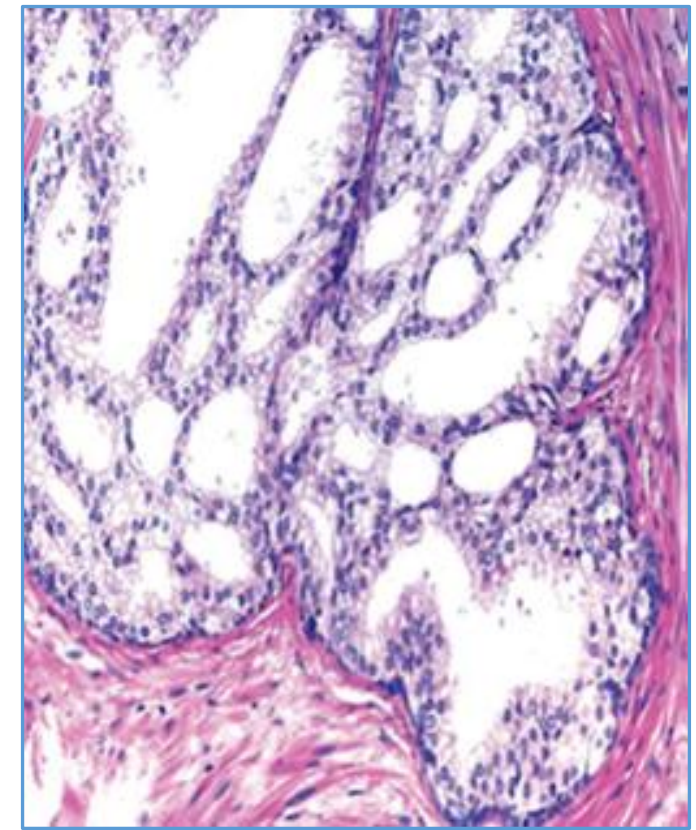

Figure 6. Microphotograph of a Case of Clear Cell Hyperplasia (100X)

\section{DISCUSSION}

We evaluated the spectrum of histomorphological lesions seen in the transurethral resection or open prostatectomy in 221 specimens. The most common morphology was that of glandular hyperplasia in the form of nodules, which was seen in $97 \%$ of cases. So, the predominant feature is epithelial hyperplasia which may be in the form of nodules or small defined foci. The nodules are composed of varying proportions of epithelial and stromal components. ${ }^{11}$ The incidence of nodules composed exclusively of stromal tissue is very low, in our study it is $2.71 \%$ and literature review reveals $3 \%-5 \% .12$ The incidence of other findings like cystically dilated glands (92\%), acute (1.2)/ chronic prostatitis (8.6\%), papillary infoldings (53.2\%) of epithelium, Corpora amylacea $(68 \%)$ and proteinaceous material in glands $(13.54 \%)$ were same as reported in the literature. ${ }^{12}$ These morphological features do not pose difficulty in distinguishing from adenocarcinoma prostate. The incidence of infarct $(27 \%)$ and gland necrosis was high in our study when compared with available literature. ${ }^{13}$ The incidence of calcification in our study is low when compared with available literature. ${ }^{14}$ The incidence of squamous metaplasia is $6 \%$ and is comparable with available literature. Squamous metaplasia should not be confused with squamous cell carcinoma and squamous cell carcinoma of prostate is exceptionally rare. 15 The incidence of transitional cell metaplasia was $5.5 \%$, which is quite high as compared to available literature. 16 The importance of transitional cell metaplasia is that it has to be distinguished from transitional cell carcinoma. Transitional cell carcinoma is the most common metastatic tumour of prostate. ${ }^{17}$ Basal cell hyperplasia was seen in $4.5 \%$ of our cases, which is comparable with that reported in literature.18 Basal cell hyperplasia is important to diagnose, because it can be confused with prostatic adenocarcinoma. ${ }^{19}$ Basal cell hyperplasia consists of numerous small to normal sized, round basophilic acini with several layers of basal cells or solid nests, either arranged in a lobular configuration or seldom infiltrating into the stroma. ${ }^{10}$ There is always an accompanying nodular hyperplasia and merging of the two processes. Florid basal cell hyperplasia and atypical basal cell hyperplasia are its other variants. ${ }^{20,21,22}$ Basal cell hyperplasia should be distinguished from basal cell carcinoma. Basal cell carcinoma is characterised by extensive infiltration between normal prostate glands, extension out of prostate, perineural invasion and necrosis. ${ }^{23}$ MIB-1 labelling index is usually below $5 \%$ in basal cell hyperplasia, whereas in basal cell carcinoma it is very high. Bcl-2 can also help in this distinction. Bcl-2 is not expressed in basal cell hyperplasia. ${ }^{10}$ Cribriform hyperplasia was seen in $0.45 \%$ of cases, which is comparable with that reported in the literature. Cribriform hyperplasia is usually seen in transition zone and is part of benign nodular epithelial hyperplasia. ${ }^{24}$ It has a nodular appearance and intervening cellular stroma is also seen. It is characterised by a crowded proliferation of complex glands having round lumina and clear cytoplasm. The cells lining the cribriform hyperplasia are cuboidal to low columnar with uniform round nuclei, clear cytoplasm and inconspicuous nucleoli. Basal cells are present. Cribriform hyperplasia is to be distinguished from cribriform prostatic adenocarcinoma. This distinction is made on the low power nodularity, cellular stroma, presence of basal cells and lack of cytological atypia. ${ }^{10}$ Atypical adenomatous hyperplasia $(\mathrm{AHH})$ was seen in $8 \%$ of the cases. The incidence is comparable with the incidence reported in the literature, i.e. $1.5 \%-19.6 \% .25,26,27$ Atypical adenomatous hyperplasia is characterised by a nodular proliferation of closely packed small glands that often merge with larger more complex glands. It is a common mimic of prostatic adenocarcinoma on both needle biopsy and transurethral resection specimen. Sometimes there is a prominent perinodular distribution of the abnormal glands. On microscopic examination, these lesions resemble prostatic adenocarcinoma grade 1 and 2. Sometimes the acini show more extensive crowding and non-lobular distribution termed diffuse adenosis. ${ }^{8}$ Immunohistochemistry reveals positivity for PSA and PAP, upto $18 \%$ of cases express AMACR. ${ }^{28}$ Immunohistochemistry reveals these lesions are negative for basal cells in about half of glands $(10 \%$ 90\%). ${ }^{29,30}$ Distinguishing features between atypical adenomatous hyperplasia and adenocarcinoma are given in Table 2.10

\begin{tabular}{|c|c|}
\hline $\begin{array}{c}\text { Atypical Adenomatous } \\
\text { Hyperplasia (Adenosis) }\end{array}$ & Prostate Cancer \\
\hline Lobular & Haphazard growth pattern \\
\hline $\begin{array}{c}\text { Small glands share features } \\
\text { with admixed larger glands }\end{array}$ & $\begin{array}{c}\text { Small glands differ from } \\
\text { adjacent benign glands }\end{array}$ \\
\hline Pale-clear cytoplasm & Amphophilic cytoplasm \\
\hline Medium-sized nucleoli & Occasionally large nucleoli \\
\hline $\begin{array}{c}\text { Blue mucinous secretions are } \\
\text { rare }\end{array}$ & $\begin{array}{c}\text { Blue mucinous secretions } \\
\text { are common }\end{array}$ \\
\hline Basal cells present & Basal cells absent \\
\hline Corpora amylacea are common & Corpora amylacea are rare \\
\hline
\end{tabular}

Atrophy includes simple atrophy, post-atrophic hyperplasia and partial atrophy. ${ }^{31}$ These patterns are often mixed. Simple atrophy may show cyst formation. Proliferative atrophy and proliferative inflammatory atrophy are optional terms. Simple atrophy and post-atrophic hyperplasia do not generally pose a diagnostic problem. Immunohistochemistry for basal cells is helpful in difficult cases. ${ }^{32}$ Partial atrophy also show lobular architecture, but this is not always as it can also show diffuse and disorganised growth pattern. The 
glands in partial atrophy do not show atrophic, basophilic appearance, instead glands have pale scant cytoplasm. ${ }^{32}$ The features seen in partial atrophy that create problem to distinguish it from prostatic adenocarcinoma are crowded and sometimes disorganised pattern of growth, relative high nuclear to cytoplasmic ratio with slightly enlarged nuclei, straight luminal borders in some glands, presence of visible yet small nucleoli, ${ }^{29}$ negativity of some of the glands for basal cell markers and positivity of some glands for alphamethylacyl coenzyme A racemase (AMACR). Atrophic adenocarcinoma also exists ${ }^{10}$; partial atrophy differs from atrophic adenocarcinoma, in that adenocarcinoma have more infiltrative pattern where the cancer glands infiltrate as isolated glands in between benign glands. There is associated atrophic adenocarcinoma, prominent cytological atypia and negative immunohistological stains for basal cells. ${ }^{32}$

\section{CONCLUSION}

Histomorphological lesions in the differential diagnosis of adenocarcinoma prostate are atrophy including partial atrophy, atypical adenomatous hyperplasia, basal cell hyperplasia, cribriform hyperplasia and crowded benign glands. These lesions mimic low-grade adenocarcinoma prostate (Gleason grade < 3). Immunohistochemistry for basal cell markers (34 beta E12, p63), prostatic adenocarcinoma (AMACR) and prostate lineage specific markers (PSA and PAP) provide significant objective evidence whether the lesion is benign or malignant. Immunohistochemistry show overlapping staining reactions in many of these lesions, so final diagnosis has to be on morphological context and to be correlated with the original $\mathrm{H}$ and $\mathrm{E}$ derived diagnosis.

\section{REFERENCES}

[1] Moore RA. Benign Hypertrophy of the prostate. A morphological study. J Urol 1943;50(6):680-710.

[2] Berry SJ, Coffey DS, Walsh PC, et al. The development of human benign prostatic hyperplasia with age. J Urol 1984;132(3):474-9.

[3] Le BV, Schaeffer AJ. Genitourinary pain syndromes, prostatitis and lower urinary tract symptoms. Urol Clin North Am 2009;36(4):527-36.

[4] Patel AK, Chapple CR. Medical management of lower urinary tract symptoms in men: current treatment and future approaches. Nat Clin Pract Urol 2008;5(4):2119.

[5] Walsh PC. Treatment of benign prostatic hyperplasia. N Eng J Med 1996;335(8):586-7.

[6] Sailer V, Kristiansen G. Histopathological screening for prostate carcinoma: is a benign biopsy a negative biopsy? APMIS 2014;122(8):690-8.

[7] Hsing AW, Chokkalingam AP. Prostate cancer epidemiology. Front Biosci 2006;11:1388-413.

[8] Hameed 0, Humphrey PA. Pseudoneoplastic mimics of prostate and bladder carcinomas. Arch Pathol Lab Med 2010;134(3):427-43.

[9] Srigley JR. Benign mimickers of prostatic adenocarcinoma. Mod Pathol 2004;17(3):328-48.

[10] Montironi R, Scarpelli M, Mazzuchelli R, et al. The spectrum of morphology in non-neoplastic prostate including cancer minics. Histopathology 2012;60(1):41-58
[11] Price H, McNeal JE, Stamey TA. Evolving patterns of tissue composition in benign prostatic hyperplasia as a function of specimen size. Hum Pathol 1990;21(6): 578-85.

[12] Mittal BV, Amin MD, Kinare SG. Spectrum of histologic lesions in 185 consecutive prostatic specimens. J Postgrad Med 1989;35(3):157-61.

[13] Milord RA, Kahane H, Epstein JI. Infract of the prostate gland: experience on needle biopsy specimens. Am J Surg Pathol 2000;24(10):1378-84.

[14] Smith MJ. Prostatic corpora amylacea. Monogr Surg Sci 1966;3(3):209-65.

[15] Mostofi FK, Morse WH. Epithelial metaplasia in prostatic infarction. Arch Pathol 1951;51:340-5.

[16] Yantiss RK, Young RH. Transitional cell, metaplasia in the prostate gland. A survey of its frequency and features based on 103 consecutive prostatic biopsy specimens. J Urol Pathol 1997;7:71-80.

[17] Mahadevia PS, Koss LG, Tar IJ. Prostatic involvement in bladder cancer. Prostate mapping in 20 cystoprostatectomy specimens. Cancer 1986;58(9):2096-102.

[18] Thorson P, Swanson PE, Vollmer RT, et al. Basal cell hyperplasia in the peripheral zone of the prostate. Mod Pathol 2003;16(6):598-606.

[19] van de Voorde W, Baldewijns M, Lauweryns J. Florid basal cell hyperplasia of the prostate. Histopathology 1994;24(4):341-8.

[20] Yang XJ, Tretiakova MS, Sengupta E, et al. Florid basal cell hyperplasia of the prostate: a histological, ultrastructural and immunohistochemical analysis. Hum Pathol 2003;34(5):462-70.

[21] Epstein JI, Armas OA. Atypical basal cell hyperplasia of the prostate. AMJ Surg Pathol 1992;16(12):1205-14.

[22] Montironi R, Mazzucchelli R, Stramazzotti D, et al. Basal cell hyperplasia and basal cell carcinoma of the prostate: a comprehensive review and discussion of a case with c-erbB-2 expression. J Clin Pathol 2005;58(3):290-6.

[23] Frauenhoffer EE, Ro JY, el-Naggar AK, et al. Clear cell cribriform hyperplasia of the prostate. Immunohistochemical and DNA flow cytometric study. Am J Clin Pathol 1991;95(4):446-53.

[24] Bostwick DG, Srigley J, Grignon D, et al. Atypical adenomatous hyperplasia of the prostate: morphologic criteria for its distinction from well differentiated carcinoma. Hum Pathol 1993;24(8): 819-32.

[25] Gaudin PB, Epstein JI. Adenosis of the prostate. Histologic features in transurethral resection specimens. Am J Surg Pathol 1994;18(9):863-70.

[26] Gaudin PB, Epstein JI. Adenosis of the prostate. Histologic features in needle biopsy specimens. Am J Surg Pathol 1995;19(7):737-47.

[27] Yang XJ, Wu CL, Woda BA, et al. Expression of amethylacyl-CoA racemase (P504S) in atypical adenomatous hyperplasia of the prostate. Am J Surg Pathol 2002;26(7):921-5.

[28] Oppenheimer JR, Wills ML, Epstein JI. Partial atrophy in prostate needle cores: another diagnostic pitfall for the surgical pathologist. Am J Surg Pathol 1998;22(4):440-5. 
[29] Przybycin CG, Kunju LP, Wu AJ, et al. Partial atrophy in prostate needle biopsies: a detailed analysis of its morphology, immunophenotype and cellular kinetics. Am J Surg Pathol 2008;32(1):58-64.

[30] De Marzo AM, Platz EA, Epstein JI, et al. A working group classification of focal prostate atrophy lesions. Am J Surg Pathol 2006;30(10):1281-91.
[31] Brimo F, Epstein JI. Selected common diagnostic problems in urological pathology: perspectives from a large genitourinary pathology consult service. Arch Pathol Lab Med 2012;136(4):360-71.

[32] Cina SJ, Epstein JI. Adenocarcinoma of the prostate with atrophic features. Am J Surg Pathol 1997;21(3):289-95. 